\title{
Effect of Pre Harvest Treatments on Growth, Flowering, Yield and Vase Life of Gerbera jamesonii cv. Red Gem
}

\author{
Nini R. Kuotsu*, Rokolhuii Keditsu and Laishram Hemanta \\ Department of Horticulture, School of Agricultural Sciences and Rural Development, \\ Nagaland University, Medziphema-797106, Nagaland, India \\ *Corresponding author
}

\section{A B S T R A C T}

\section{Keywords}

Gerbera, Gibberellic acid (GA3), Maleic hydrazide (MH), Naphthalene Acetic Acid (NAA)

Article Info

Accepted:

12 April 2018

Available Online:

10 May 2018
An experiment was conducted on gerbera plants where ten treatments consisting of Control, $\mathrm{GA}_{3}(50,100,150 \mathrm{ppm}), \mathrm{MH}(200,250,300 \mathrm{ppm})$ NAA $(200,250,300 \mathrm{ppm})$ were replicated three times and given a single spray at 2 months after planting in pots. Results revealed that the best treatment with respect to growth and flowering was with $\mathrm{GA}_{3} 100 \mathrm{ppm}$. While $\mathrm{GA}_{3} 100$ and $150 \mathrm{ppm}$ were proved to be the best in yield attributes and $\mathrm{MH} 250 \mathrm{ppm}$ proved to be significantly better in influencing the vase life of cut gerbera flowers as compared to the various treatments under study.

\section{Introduction}

Gerbera (Gerbera jamesonii) is an important cut flower having good demand both in the domestic and international markets. The flower occupies the $5^{\text {th }}$ position among the most important cut flowers of the global floriculture market. The rate of demand in ornamental products such as cut flowers and potted plants has gained a great momentum which has far surpassed the rate of supply. The growth and yield of plants is mainly influenced by two principle factors viz., genetic and cultivation or management factors. In recent years scientist have given due attention to the idea of regulating plant growth as third most important factor in improving the growth, yield and flower quality with the application of plant growth regulators in various ways. Growth regulators are known to have significant effect even in very small quantities and have been used in several ornamental crops. These substances modify the plant physiological processes within the plant, which ultimately affects plant growth and development. They are also expensive chemicals as such their optimum dose to get the targeted result needs to be standardized for the cultivation practice to be cost effective. Application of certain nutrients and growth regulators as foliar feeding has been found to improve growth and flowering of gerbera because high percentage of the nutrients is immediately absorbed by the leaves which 
influence the growth and development of plant and improve the quality of flower as well as increase the yield of cut flowers and suckers. Foliar application of growth chemicals also reduces the cost of production (Jamal Udin et al., 2011). However, the research work on this aspect of agro-technique in gerbera plants is lacking and so with a view to this, an investigation was carried out to study the effect of foliar application of plant growth regulators on growth, flowering, yield and vase life of Gerbera jamesonii cv. Red Gem.

\section{Materials and Methods}

The experiment was conducted in the month of June-December in the year 2012 in the Experimental Farm of Horticulture Department in Nagaland University, School of Agricultural Sciences and Rural Development, Medziphema Nagaland. Plants of gerbera cv. Red Gem were pot cultured for the study. Ten treatments consisting of: $\mathrm{T}_{0}-$ Control, $\mathrm{T}_{1}-50$ ppm $\mathrm{GA}_{3}, \mathrm{~T}_{2}-100$ ppm $\mathrm{GA}_{3}, \mathrm{~T}_{3}-150 \mathrm{ppm}$ $\mathrm{GA}_{3}, \mathrm{~T}_{4}-200 \mathrm{ppm} \mathrm{MH}, \mathrm{T}_{5}-250 \mathrm{ppm} \mathrm{MH}, \mathrm{T}_{6}$ - 300 ppm $\mathrm{MH}, \mathrm{T}_{7}-200$ ppm NAA, $\mathrm{T}_{8}-250$ ppm NAA and $\mathrm{T}_{9}-300$ ppm NAA were tested.

The plants were given a single spray of the treatments at two months after planting. The experiment was carried out in a completely randomized design with three replications where each pot containing one number of suckers was taken as a unit. The pots were filled with a mixture of soil: sand: FYM in a 1:1:1 ratio and NPK @ 250:250:100 kg/ha was incorporated in the soil. Half dose of $\mathrm{N}$ and full dose of $\mathrm{P}$ and $\mathrm{K}$ were applied at the time of planting while the remaining half dose of $\mathrm{N}$ was applied at the time of flowering. The data pertaining to vegetative parameters, flowering attributes, yield attributes and vase life were recorded and analyzed statistically as per the method suggested by Panse and Sukhatme (1989).

\section{Results and Discussion}

\section{Effect on vegetative growth}

It was evident from Table 1 that the various pre harvest treatments under study effected the vegetative growth of the plant significantly. $\mathrm{GA}_{3}(150 \mathrm{ppm})$ resulted in greater number of leaves per plant while the highest value in terms of plant spread was recorded with $\mathrm{GA}_{3}$ @ 100 ppm $(34.33 \mathrm{~cm})$. Application of $\mathrm{GA}_{3}$ might have resulted in profuse cell division and cell elongation resulting in enhanced vegetative growth.

This finding is in concurrence with the reports of Nair et al., (2002) and Dalal et al., (2009).

The increase in production of leaves with the application of gibberellic acid was a result of enhanced induction of leaf initial break i.e. differentiation of leaf primordial in the apical growing region (Dhaduk et al., 2007). The variation in plant height due to different treatments was found to be insignificant.

However, the maximum plant height was recorded with NAA @ 200 ppm $(26.33 \mathrm{~cm})$. The increase in plant height as an influence of NAA application was also reported by Sooch et al., (2002). Leaf area was not significantly influenced by the different pre harvest treatments. However, the maximum leaf area was observed in $\mathrm{MH} @ 300$ ppm (105.00 $\mathrm{cm}^{2}$ ).

\section{Effect on flowering}

A perusal of the data in Table 1 revealed that minimum number of days taken for bud emergence, bud burst and full bloom were recorded in $\mathrm{GA}_{3}$ treatments. Among the $\mathrm{GA}_{3}$ doses, 150 ppm significantly reduced the number of days taken to full bloom (141 days). These results corroborated with the findings of Dalal et al., (2009). 


\begin{tabular}{|c|c|c|c|c|c|c|c|}
\hline \multirow[b]{2}{*}{ Treatments } & \multicolumn{4}{|c|}{ Vegetative characters } & \multirow{2}{*}{$\begin{array}{l}\text { Bud } \\
\text { emergence } \\
\text { (days) }\end{array}$} & \multirow{2}{*}{$\begin{array}{l}\text { Bud burst } \\
\text { (days) }\end{array}$} & \multirow{2}{*}{$\begin{array}{l}\text { Full bloom } \\
\text { (days) }\end{array}$} \\
\hline & $\begin{array}{l}\text { Number } \\
\text { of leaves }\end{array}$ & $\begin{array}{l}\text { Plant spread } \\
(\mathrm{cm})\end{array}$ & $\begin{array}{l}\text { Leaf area } \\
\left(\mathrm{cm}^{2}\right)\end{array}$ & $\begin{array}{l}\text { Plant height } \\
\text { (cm) }\end{array}$ & & & \\
\hline$T_{0}$ & 70.67 & 32.00 & 98.67 & 23.33 & 125.67 & 137.33 & 147.00 \\
\hline$T_{1}$ & 68.33 & 30.67 & 103.67 & 23.50 & 125.00 & 136.33 & 145.00 \\
\hline $\mathbf{T}_{2}$ & 67.33 & 34.33 & 97.33 & 24.33 & 125.33 & 136.00 & 144.33 \\
\hline$T_{3}$ & 77.33 & 32.67 & 90.33 & 24.00 & 124.33 & 134.00 & 141.00 \\
\hline $\mathbf{T}_{4}$ & 61.00 & 30.33 & 89.00 & 22.17 & 126.33 & 137.00 & 148.67 \\
\hline$T_{5}$ & 67.00 & 30.33 & 92.00 & 23.67 & 126.67 & 137.00 & 148.33 \\
\hline $\mathrm{T}_{6}$ & 60.67 & 32.17 & 105.00 & 22.00 & 126.67 & 138.00 & 151.67 \\
\hline$T_{7}$ & 40.00 & 33.83 & 85.67 & 26.33 & 128.67 & 139.67 & 152.67 \\
\hline$T_{8}$ & 57.00 & 31.67 & 90.67 & 24.33 & 127.00 & 138.67 & 147.67 \\
\hline$T_{9}$ & 36.67 & 33.00 & 96.33 & 26.00 & 130.67 & 143.00 & 158.67 \\
\hline $\mathrm{CD}$ at $5 \%$ & 23.21 & NS & NS & NS & NS & NS & 7.78 \\
\hline
\end{tabular}

\begin{tabular}{|l|l|l|l|l|l|l|l|l|l|}
\hline \multicolumn{7}{|c|}{ Table.2 Floral attributes as affected by pre harvest treatments } \\
\hline Treatments & $\begin{array}{l}\text { Fresh } \\
\text { weight } \\
(\mathrm{g})\end{array}$ & $\begin{array}{l}\text { Flower } \\
\text { size } \\
(\mathrm{cm})\end{array}$ & $\begin{array}{l}\text { Diameter of } \\
\text { disc florets } \\
(\mathrm{cm})\end{array}$ & $\begin{array}{l}\text { Stalk } \\
\text { length } \\
(\mathrm{cm})\end{array}$ & $\begin{array}{l}\text { Stalk } \\
\text { diameter } \\
(\mathrm{cm})\end{array}$ & $\begin{array}{l}\text { Neck } \\
\text { diameter } \\
(\mathrm{cm})\end{array}$ & $\begin{array}{l}\text { Number } \\
\text { of ray } \\
\text { florets }\end{array}$ & $\begin{array}{l}\text { Number of } \\
\text { disc } \\
\text { florets }\end{array}$ & $\begin{array}{l}\text { Self- } \\
\text { life } \\
(\text { days })\end{array}$ \\
\hline $\mathrm{T}_{0}$ & 11.00 & 8.80 & 6.23 & 24.67 & 0.53 & 0.40 & 39.00 & 216.00 & 17.00 \\
\hline $\mathrm{T}_{1}$ & 13.00 & 9.87 & 6.83 & 29.10 & 0.63 & 0.47 & 43.00 & 236.00 & 18.67 \\
\hline $\mathrm{T}_{2}$ & 14.00 & 10.10 & 7.07 & 32.93 & 0.60 & 0.50 & 47.67 & 328.67 & 16.33 \\
\hline $\mathrm{T}_{3}$ & 12.67 & 9.17 & 6.70 & 28.30 & 0.53 & 0.43 & 43.33 & 244.33 & 15.67 \\
\hline $\mathrm{T}_{4}$ & 11.67 & 8.93 & 6.57 & 28.30 & 0.53 & 0.43 & 34.33 & 207.33 & 18.00 \\
\hline $\mathrm{T}_{5}$ & 13.00 & 9.33 & 6.67 & 35.00 & 0.57 & 0.43 & 41.67 & 220.33 & 19.33 \\
\hline $\mathrm{T}_{6}$ & 13.33 & 9.53 & 6.57 & 36.17 & 0.60 & 0.50 & 45.00 & 260.00 & 15.67 \\
\hline $\mathrm{T}_{7}$ & 13.67 & 9.50 & 6.83 & 41.67 & 0.63 & 0.50 & 39.67 & 215.67 & 12.00 \\
\hline $\mathrm{T}_{8}$ & 12.67 & 8.63 & 6.10 & 42.23 & 0.57 & 0.40 & 41.67 & 200.33 & 18.67 \\
\hline $\mathrm{T}_{9}$ & 13.67 & 9.17 & 6.27 & 42.77 & 0.57 & 0.47 & 46.00 & 214.33 & 15.00 \\
\hline $\mathrm{CD}$ at 5\% & 1.98 & 1 & NS & 8.09 & NS & 0.08 & NS & NS & 4.51 \\
\hline
\end{tabular}

\begin{tabular}{|l|c|c|c|}
\hline \multicolumn{3}{|c}{ Table.3 Effect of pre harvest treatments on yield and vase life of Gerbera } \\
\hline & $\begin{array}{l}\text { Yield parameters } \\
\text { No. of flowers/plant }\end{array}$ & No. of suckers/plant & Vase life (days) \\
\hline $\mathrm{T}_{0}$ & 13.00 & 11.00 & 9.00 \\
\hline $\mathrm{T}_{1}$ & 17.67 & 10.67 & 11.00 \\
\hline $\mathrm{T}_{2}$ & 20.00 & 11.00 & 11.33 \\
\hline $\mathrm{T}_{3}$ & 19.67 & 12.67 & 10.00 \\
\hline $\mathrm{T}_{4}$ & 15.67 & 10.33 & 12.67 \\
\hline $\mathrm{T}_{5}$ & 15.33 & 11.67 & 14.33 \\
\hline $\mathrm{T}_{6}$ & 13.33 & 10.67 & 13.00 \\
\hline $\mathrm{T}_{7}$ & 12.00 & 7.00 & 9.33 \\
\hline $\mathrm{T}_{8}$ & 12.33 & 9.00 & 10.00 \\
\hline $\mathrm{T}_{9}$ & 11.67 & 6.67 & 9.33 \\
\hline $\mathrm{CD}_{2}$ at 5\% & 6.17 & 3.70 & 3.19 \\
\hline
\end{tabular}


The data in Table 2 depicted that the maximum flower size was obtained in $\mathrm{GA}_{3} @$ $100 \mathrm{ppm}(10.10 \mathrm{~cm})$ which is statistically at par with $\mathrm{GA}_{3} @ 50$ ppm $(9.87 \mathrm{~cm})$. This is in conformity with the findings of Jadhao et al., (2010). The effect of various pre harvest treatments was non-significant with respect to number of ray florets and disc florets. However, the maximum number was obtained in $\mathrm{GA}_{3} @ 100$ ppm (47.67) and (328.67) respectively. While the lowest number of disc floret (200.33) was recorded in NAA @ 250 ppm. GA 3 @100 ppm produced maximum diameter $(7.07 \mathrm{~cm})$ of disc floret but this result did not reach the level of significance. Increase in flower characters with $\mathrm{GA}_{3}$ application may be attributed to active cell elongation in the flowers to increase the sink strength of the actively growing parts. Gibberillic acid has been reported to induce an entire developmental programme by activation of master regulatory genes in the later stages of corolla development (Weiss, 2000). Treatment with 300 ppm NAA registered maximum length of flower stalk $(42.77 \mathrm{~cm})$ which was statistically at par with 250 ppm NAA $(42.23 \mathrm{~cm})$ and 200 ppm NAA $(41.67 \mathrm{~cm})$. Stalk diameter did not vary significantly due to pre harvest treatments. However, 50 ppm $\mathrm{GA}_{3}$ and 200 ppm NAA recorded the highest stalk diameter $(0.63 \mathrm{~cm})$. The highest neck diameter of $0.50 \mathrm{~cm}$ was obtained with the application of $\mathrm{GA}_{3} @ 100$ ppm, MH@ @ 300 ppm and NAA @ 200 ppm. $\mathrm{GA}_{3} @ 100$ ppm recorded the highest fresh weight (14.00 g) which was on par with NAA @ 200 and 300 ppm (13.67 g) whereas minimum fresh weight was recorded in control. The favorable effect of growth regulators might be due to cell elongation and rapid cell stimulation as has been reported by Singh (2004) in French marigold. The highest self-life was recorded in $250 \mathrm{ppm} \mathrm{MH} \mathrm{(19.33}$ days). Increased flower life with $\mathrm{MH}$ application might be due to retarded metabolism and respiration (Nair et al., 2002).

\section{Effect on yield}

Out of the 10 treatments evaluated for their yield parameters (Table 3) the maximum number of flowers per plant was observed in $\mathrm{GA}_{3}$ treatments followed by $\mathrm{MH}$ treatments. $\mathrm{GA}_{3} @ 100$ ppm gave a significantly higher number of flowers per plant (20.00) which is on par with $\mathrm{GA}_{3} @ 150$ ppm (19.67). The increase in yield and yield parameters with $\mathrm{GA}_{3}$ spray may be due to better crop growth and more number of suckers thus increased the number of flowers per plant. Further, it can be ascribed due to better translocation of more metabolites from source to sink. Similar findings were reported by Nair et al., (2002) in Gerbera. The maximum number of suckers per pot was recorded with $\mathrm{GA}_{3} @ 150$ ppm (12.67). This might be due to the action of $\mathrm{GA}_{3}$ in producing more number of leaves and after diversion of the photosynthates to the sink, the rest would have been used for the production of suckers. This is in close conformity with the findings of Nair et al., (2002).

\section{Effect on vase life}

Data in Table 3 showed that the vase life was profoundly influenced by the different pre harvest treatments where $250 \mathrm{ppm} \mathrm{MH}$ recorded the maximum vase life (14.33 days). The minimum vase life was recorded in control (9.00 days). Similar results were also obtained in the findings of Nouri et al., (2012). The reason for longer vase life in $\mathrm{MH}$ treated plants might be due to the action of $\mathrm{MH}$ in reducing the stomatal size and hence reducing the rate of respiration. Since the rate at which the rapid decline in water conduction of isolated stem segments was much reduced by $\mathrm{MH}$, this might have resulted in better water balance within the plant (Nair et al., 2002). From the above findings, it may be concluded that the best treatment with respect to growth and flowering was with $\mathrm{GA}_{3} 100$ 
ppm. While $\mathrm{GA}_{3} 100$ and $150 \mathrm{ppm}$ were proved to be the best in yield attributes and MH $250 \mathrm{ppm}$ proved to be significantly better in influencing the vase life of cut gerbera flowers as compared to the other treatments under study.

\section{References}

Dalal, S. R., Somavanshi, A. V. and Karale, G. D. (2009), Effect of gibberellic acid on growth, flowering, yield and quality of gerbera under polyhouse conditions. International Journal of Agricultural Science”, Vol. 5: pp. 355-356.

Dhaduk, B.K., Kumari, S., Singh, A. and Desai J.R. (2007), "Response of gibberellic acid on growth and flowering attributes in anthurium (Anthurium andreanum Lind.)". Journal of Ornamental Horticulture, Vol. 10: pp. 187-189.

Jadhao, A., Tamgadge, S., Deshmukh, A., Telgote, N. and Bodakhe, V. (2010), "Effect of nitrogen levels and gibberellic acid on growth and yield of gerbera under polyhouse condition." Asian Journal of Horticulture, Vol. 5: pp. 341-343.

Jamal Udin, A.F.M., Islam, M.S., Shammy, F.H., Das, C., Hossan, M.J. and Habiba, S.U. (2011), "Foliar application of growth chemicals on growth, coloration and yield of chrysanthemum (Chrysanthemum sp.)." Bangladesh Research Publications Journal, Vol. 5: pp. 314-320.

Nair, S. A., Singh, V. and Sharma T.V.R.S. (2002), "Effect of plant growth regulators on yield and quality of gerbera under Bay Island conditions." Indian Journal of Horticulture, Vol. 59: pp. 100-105.

Nouri, N., Abdossi, V. and Boojar, M. (2012), "The effect of Gibberellic acid and Benzyladenin on post-harvest quality and vase life of Alstroemeria cultivar may fair cut flowers with enzymatic assay. (Special issue.)." International Journal of Agriculture Research and Review, Vol. 2: pp. 1025-1031,

Panse, V. G. and Sukhatme, P. V. (1989), "Statistical Methods for Agricultural Workers", Indian Council of Agricultural Research, New Delhi.

Roy, B. and Mandal, A.B. (2005), "Toward Development of Al-toxicity Tolerant Lines in Indica Rice by Exploiting Somaclonal Variation", Euphytica, Vol. 145(3), pp. 221-227.

Singh, A.K. (2004), "Influence of plant bio regulators on growth and seed yield in French marigold (Tagetes patula L.)." Journal of Ornamental Horticulture, Vol. 7: pp. 192-195.

Sooch, S., R. Kumar and Sooch, M. (2002), "Effect of NAA and Kinetin on plant growth and flower production in carnation." Proceedings of the National Symposium on Indian Floriculture in the new millennium, pp. 295-297.

Weiss, D. (2000), "Regulation of flower pigmentation and growth: multiple signaling pathways control anthocyanin synthesis in expanding petals." Physiologia Plantarum, Vol. 110: pp. 152-157.

\section{How to cite this article:}

Nini R. Kuotsu, Rokolhuii Keditsu and Laishram Hemanta. 2018. Effect of Pre Harvest Treatments on Growth, Flowering, Yield and Vase Life of Gerbera jamesonii cv. Red Gem. Int.J.Curr.Microbiol.App.Sci. 7(05): 1537-1541. doi: https://doi.org/10.20546/ijcmas.2018.705.181 